\title{
SPIRITUALITAS LUKISAN AMANG RAHMAN JUBAIR
}

\section{Hajriansyah}

\author{
KASISAB Institute Banjarmasin \\ Hajrian@yahoo.com
}

\begin{abstract}
:
This study focused on the spirituality values in paintings of Amang Rabman Jubair, particularly from the perspective of the sufi aesthetics. Amang Rabman (1931-2001) was an Indonesian painter which has a deeply awareness of God's presence, and have a concept of art which he called Jamal, Kamal and Jalalembodied by the sweat, blood and tears, which means sacrifice, devotion and love to the Creator and His creatures. Forms of this study is a qualitative field research by using descriptive analytical method and approach of Sufi Aesthetics. The sources is the family and closest-friends of Amang Rahman, a few paintings and journalistic articles and Indonesian art critics writings of his works. This study suggests that Amang Rahman is a sufi in a modern world. Experiences and attitudes totality of his life proving his devotion to both the art and life itself intact. In the works of his art reflected awareness of space and the cosmos that represents nature imajinal ('alam al-khayal), traditions and symbols of Sufism.
\end{abstract}

Keywords: Spirituality, Art Painting, Amang Rabman Jubari, Sufi Aesthetics.

\section{Pendahuluan}

Sufisme adalah ajaran dan doktrin yang memberikan suatu jalan (praktek), yang ditujukan pada kesadaran yang mendalam akan Tuhan. Dalam pengandaian yang umum, berdasarkan hadis Nabi, kesadaran semacam ini sering diidentikkan dengan ihsan, yaitu merasa seakan-akan melihat Allah, atau setidaknya merasa selalu diawasi oleh-Nya. Jalan yang bersifat spiritual atau rohaniah ini merupakan fitrah manusia yang ingin mencapai hakikat (pengetahuan) yang tinggi, berada dekat atau sedekat mungkin dengan sang pencipta, yaitu Allah swt, dengan menyucikan dan melepaskan jiwa dari 
keterpenjaraan jasad yang bersifat kebendaan, di samping melepaskan jiwa dari noda-noda sifat dan perbuatan yang tercela. ${ }^{1}$

Di dalam sejarahnya yang panjang manifestasi ajaran dan praktek tasawuf ini tidak dapat dipungkiri menghasilkan bentuk-bentuk kesenian yang khas dan beragam, dari puisi hingga arsitektur. Sebagaimana disebutkan oleh Seyyed Hossein Nasr, bahwa di lapangan seni dan ilmu pengetahuan pengaruh sufisme atau tasawuf sangatlah besar. Islam sendiri menyebut salah satu aspek penting ilahi sebagai keindahan (jamal), dan gambaran ini khususnya sangat ditekankan dalam tasawuf, yang secara kodrati timbul dari Islam dan mengandung hal-hal yang hakiki. ${ }^{2}$

Lebih lanjut menurut Nasr, salah satu aspek yang paling berkaitan dengan pesan spiritual seni Islam saat ini adalah kemampuannya dalam menyampaikan esensi Islam melalui cara yang lebih langsung dan dapat dipahami dibandingkan penjelasan yang ilmiah semata. Seni Islam dianggapnya menjadi medium yang efektif dalam menyampaikan pesan spiritual Islam. Sebaris kaligrafi tradisional atau dekorasi arabeska dapat berbicara lebih cakap tentang intelegensi dan kemuliaan yang menjadi karakter pesan Islam dibandingkan karya apologis para modernis atau para aktivis. ${ }^{3}$ Para sufi adalah pengolah seni, bukan karena seni merupakan tujuan para sufi, melainkan dengan mengikuti tasawuf seseorang akan menjadi sadar akan keindahan Ilahi yang menyatakan diri-Nya di mana-mana, dan berdasarkan yang demikian para sufi menciptakan benda-benda yang indah yang memancarkan keindahan sang Seniman Agung. ${ }^{4}$

Seni lukis sebagai salah satu cabang kesenian yang sangat tua telah menjadi medium untuk menyampaikan pesan-pesan kemanusiaan, baik yang bersifat lahiriah maupun yang spiritual. Dalam prakteknya selama berabadabad, dalam banyak peradaban, yang bersifat mistik maupun non-mistik, lukisan menjadi ekspresi individu-kerohanian (tidak terbatas dalam pengertian spiritual), dari tadinya bersifat anonim dan ada kalanya oleh kelompok-yang kemudian menjadi sangat individual, dalam mencurahkan pikiran dan perasaan akan hal-hal yang dipandang indah. Aspek-aspek keindahan ini seiring waktu memiliki banyak dimensi, dengan begitu estetika menjadi ilmu yang cukup luas

\footnotetext{
1 M. Shoim Anwar, "Lukisan Non-Kaligrafi Amang Rahman Lebih Menggiring Ke Transendensi," Surabaya Post, February 19, 1994.hlm. 145-149.

${ }^{2}$ Seyyed Hossein Nasr, Tasauf Dulu Dan Sekarang (Jakarta: Pustaka Firdaus, 2002). hlm. xxiii

${ }^{3}$ Seyyed Hossein Nasr, Spiritualitas Dan Seni Islam (Bandung: Mizan, 1993). hlm. 213.

${ }^{4}$ Nasr, Tasauf Dulu Dan Sekarang. hlm. xxv.
} 
dalam menerjemahkan keindahan menurut persepsi yang beragam itu. Dalam aspeknya yang mistik-misalnya pada gua Altamira di Spanyol, dan di Lascaux, barat daya Perancis, atau yang juga ditemukan di gua Leang-leang, Sulawesi Selatan, maupun di Kalimantan Timur- lukisan menjadi medium orang-orang pada masa purba untuk menjerat buruannya. Sementara di sisi lain, sebagaimana pada lukisan-lukisan Michelangelo di Chapel de Sistine (Vatikan Roma), lukisan menjadi ekspresi pesan keagamaan yang tidak sekadar bersifat spiritual, namun juga indah.

Begitu pula yang tervisualisasikan melalui kaligrafi dan arabeska yang menghiasi dinding-dinding Kubah Batu di Jerusalem, Masjid Umayyah di Damaskus, maupun di Masjid Kordoba dan Istana Alhambra Spanyol. Atau, bagaimana ilustrasi-ilustrasi seni lukis miniatur memperindah kitab-kitab keagamaan Islam pada abad pertengahannya (dan sesudahnya), entah di Mesir, Persia, Turki, Andalusia (Spanyol), dan India, dari peninggalan dinasti-dinasti Mamluk, Safawiyah, Ustmaniyah, dan Mughal.

Frithjof Schoun dalam kaitannya dengan aspek spiritualitas agamaagama, menekankan perihal "bentuk dalam seni". Jika kita ingin memahami bentuk-bentuk, katanya, perlu disadari bahwa secara simbolis justru bentuk yang dapat ditangkap secara inderawi itulah yang berkaitan langsung dengan intelek, berkat analogi terbalik yang menghubungkan tatanan asas dan perwujudan. Konsekuensi analogi ini menyatakan, realitas tertinggi terwujud paling jelas dalam cerminannya yang paling jauh, yaitu pada tatanan inderawi atau material. Ini berimplikasi pada alasan, bahwa wahyu bukan hanya turun ke dalam jiwa para nabi, melainkan juga ke dalam tubuh-jasmaninya, yang berarti bahwa tubuh-jasmani itu sendiri sempurna. ${ }^{5}$

Tulisan ini akan membicarakan pelukis Amang Rahman Jubair yang karya-karyanya menurut beberapa pemerhati/ kritikus seni rupa Indonesia memiliki unsur-unsur spiritual Islam, atau yang lazim disebut tasawuf.

Fokus penelitian atau rumusan masalah yang ingin dijawab adalah: (1) Apakah karya-karya Amang Rahman Jubair benar-benar merepresentasikan pengalaman spiritualnya? (2) Bagaimana karya-karya yang berhubungan dengan pengalaman spiritualnya itu, jika memang demikian, ditinjau dari konsep estetika sufi? Dengan demikian tujuan penelitian ini ingin, (1) Menyingkap keterhubungan gagasan antara corak lukisan Amang Rahman dengan sikap hidup dan pandangannya, serta (2) Menganalisa nilai-nilai spiritualitas dalam lukisan-lukisan Amang Rahman dengan pendekatan atau perspektif estetika

${ }^{5}$ Frithjof Schoun, Mencari Titik Temu Agama-Agama (Jakarta: Pustaka Firdaus, 1987). hlm. 67-68 
sufi. Penulis akan memaparkan dan menganalisa karya-karya seni lukisnya dalam tinjauan estetika sufi.

\section{Metode}

Penelitian ini menggunakan metode kualitatif lapangan. Penulis melakukan observasi secara langsung ke tempat-tempat di mana Amang pernah hidup dan berkesenian, seperti rumah dan studio Amang, Dewan Kesenian Surabaya (DKS), makam Amang Rahman di Surabaya, dan beberapa rumah sahabat Amang baik di Surabaya, Yogyakarta dan Bandung. Penulis mewawancarai orang-orang terdekat Amang Rahman, baik keluarga maupun sahabatnya saat ia masih hidup, di antaranya Wati Kasiyati (isteri), Salha (adik), Yunus Jubair dan Ilham Jubair (anak), Abdul Hadi W.M. (sahabat dan pemerhati seni), A.D. Pirous (sahabat dan seniman seni rupa), Henri Nurcahyo (sahabat sekaligu murid dan penulis), Djuli Djatiprambudi (sahabat dan pemerhati seni), Akhudiat (sahabat dan seniman teater), M. Agus Burhan (pemerhati seni rupa), D. Zawawi Imron (sahabat dan penyair), Sabrot D. Malioboro (sahabat dan penyair), dan Toto Sonata (sahabat dan jurnalis).

Data-data lain yang juga penting didapatkan dari dokumentasi atau bundel kliping yang dibuat oleh Bagian Dokumentasi Dewan Kesenian Jakarta, yang di dalamnya banyak terdapat wawancara dan laporan jurnalistik terkait aktivitas kesenian Amang Rahman dari tahun 1980 sampai 1990-an itu, termasuk beberapa laporan dan obituari terkait kematian Amang pada tahun 2001. Adapun menyangkut foto-foto karya, selain yang penulis buat sendiri dari yang masih terpajang sekitar 40-an karya di rumah Amang, penulis bersandar pada buku Ambang Cakrawala yang ditulis oleh Henri Nurcahyo dan Mamannoor. Data-data terkait kehidupan Amang kemudian dideskripsikan terkait latar belakang keagamaan dan keseniannya, serta aspek sosial dan sufistik kehidupannya. Sedangkan karya-karyanya setelah dipaparkan menurut pengamatan umum oleh beberapa kritikus seni, kemudian diulas dalam tinjauan estetika sufi dengan mengacu pada buku Spiritualitas dan Seni Islam karya Seyyed Hossein Nasr. Pendekatan yang digunakan Nasr ini mengandaikan adanya halhal yang bersifat suci atau sakral, dan aspek-aspek lainnya dalam konteks sufisme. 


\section{Pembahasan}

\section{Biografi Amang Rahman Jubair}

Terlahir dengan nama Abdul Rahman, nama lengkap Amang Rahman adalah Abdul Rahman bin Awad bin Jubair. Bin Jubair sendiri adalah salah satu nama marga bangsa Arab di Hadramaut dari kalangan masyâyikh (non-alawy). Nama Amang atau Mamang sebagai panggilan akrab adalah hal yang lumrah di kalangan Arab-Indonesia, sebagai kependekan dari Abdurrahman atau Abdul Rahman. ${ }^{7}$

Amang Rahman lahir di kawasan Ampel Tebasan, Surabaya, pada tanggal 20 Nopember 1931. Ia merupakan anak keempat dari 13 bersaudara, dari pasangan Awad Jubair dan Siti Rahmah. Ibunya merupakan wanita pribumi dari Sidoarjo. Ayahnya adalah seorang walayiti, ${ }^{9}$ yang berprofesi sebagai pedagang keliling sekaligus merangkap juru dakwah yang sering bepergian ke Bangkalan-Madura. Amang kecil sering mengikutinya ayahnya berdagang, bahkan sempat menetap di Madura antara tahun 1939-1945 dan sekolah rakyat dua tahun di sana. Di antara orang-orang yang dikenalnya ketika mengikuti ayahnya berdagang itu adalah Kyai Cholil Bangkalan, Kyai Imran, Kyai Badri Ketapang, dan Kyai M.Tayib.

Sikap keberagamaannya dibentuk dalam keluarga muslim yang taat beragama dan lingkungan masa kecilnya yang akrab dengan kebudayaan Jawa. Kawasan Ampel sendiri adalah sebuah pemukiman yang banyak dihuni oleh

\footnotetext{
${ }^{6}$ Masyâyikh dalam pergaulan diaspora Hadrami-Indonesia umumnya untuk menyebut mereka yang bukan dari kalangan Alawiyyin. Alawiyyin merupakan suatu keluarga besar bangsa Arab keturunan Nabi Saw di Hadramaut (Yaman), keturunan dari Imam Ahmad bin Isa al-Muhajir (generasi ke-9 dari Rasulullah) yang pertama kali hijrah ke Hadramaut dari tempat asalnya di Basrah. Nama Alawy sendiri biasa dirujukkan pada Imam Alwy bin 'Ubaidillah Shâhibul 'Ardh, cucu dari al-Muhâjir. Di dalam tradisi tasawuf, nama Alawiyyah merupakan salah satu dari tarekat mu'tabarah yang cukup populer di Indonesia. Istilah Syekh atau Masyâyikh (jamak) di Hadramaut memiliki pengertian yang berbeda, yang berarti orang-orang yang dituakan karena umur dan keilmuannya. Lihat L.W.C. Van den Berg, Orang Arab Di Nusantara (Depok: Komunitas Bambu, 2010), hlm 13-89.

7 Henri Nurcahyo and Mamannoor, Ambang Cakrawala Jakarta: Yayasan Kembang Jati, 2001).hlm. 14.

8 Tanggal ini meski dipakai secara umum, sebenarnya cukup meragukan. Karena dalam beberapa catatan yang penulis temukan ada beberapa versi tanggal, meskipun tahun kelahirannya tetap sama yaitu 1931.

${ }^{9}$ Walayiti, atau wulayiti, artinya asli kelahiran Hadramaut atau generasi pertama yang datang dari Yaman ke sebuah negeri dan menetap di sana, lawannya adalah muwallad, keturunan ArabYaman kelahiran Indonesia. Lihat Frode F. Jacobsen, Hadrami Arabs in Present-Day Indonesia, An Indonesia-Oriented Group with an Arab Signature (USA-Canada: Routledge, 2009).
} 
warga keturunan Arab. Tempat ini dikenal sejak lama sebagai lingkungan yang agamis, dengan titik sentralnya ada pada masjid peninggalan Sunan Ampel dan komplek pemakaman yang banyak diziarahi hingga kini. Selain masjid, komplek pemakaman dan pasar seng merupakan dua daya tarik bagi para peziarah. Sedangkan pendidikan formal Amang hanya sampai kelas empat Sekolah Rakyat (SR). Kelas 1 dan 2 di Sidoarjo, sedangkan kelas 3 dan 4 di Madura. Selebihnya Amang lebih banyak belajar secara informal dengan bergaul dan bertanya secara langsung pada tokoh-tokoh pendidikan dan seniman pada masanya, seperti Mohammad Said Reksohadiprodjo (dikenal sebagai Pak Said, tokoh pendidikan nasional yang pernah menjadi Pamong sekaligus Ketua Tamansiswa cabang Jakarta sejak tahun 1937 hingga 1971), Toha Muchtar Trisnojuwono (dua orang tokoh sastra Indonesia), serta Affandi dan Nashar (dua orang tokoh seni rupa Indonesia). Selain itu Amang juga senang membaca buku sejak kecil, sehingga ia mengenal tokoh-tokoh sastra Indonesia seperti Hamka, Sutan Takdir Alisyahbana, dan H.B. Jassin, yang dijadikannya guru secara imajiner.

Amang mulai aktif melukis pada tahun 1960-an akhir. Sebelumnya ia juga menggeluti dunia sastra dan teater. Pada tahun 1973, melalui sebuah kegiatan pameran seniman-seniman Surabaya di Bandung, Amang berkenalan dengan A.D. Pirous yang kemudian membawanya masuk ke dalam dunia seni rupa Islam nasional dan internasional. Sejak saat itu Amang aktif melakukan pameran lukisan, tidak hanya di Surabaya, tapi juga di beberapa kota besar di Indonesia. Hampir setiap pamerannya mendapat perhatian yang besar dari media massa Indonesia. Terhitung Amang telah melakukan pameran tunggal sebanyak tujuh kali, dan pameran bersama yang diikutinya sebanyak 56 kali di dalam dan di luar negeri, semasa hidupnya. Pada bulan Nopember 2001, delapan bulan sesudah kematian Amang, diselenggarakan pameran tunggal lukisan-lukisannya di Galeri Nasional Indonesia Jakarta, sekaligus peluncuran buku biografi dan karya-karyanya Ambang Cakrawala.

Banyak pengamat seni Indonesia yang menulis tentang karya-karya seni lukis Amang Rahman, di antaranya adalah Abdul Hadi W.M. yang menyebutnya sebagai pelukis surealis-sufistik. Djuli Djatiprambudi (akademisi seni rupa dari Surabaya) menyebut Amang sebagai salah satu tonggak sejarah seni rupa modern di Surabaya. Karena, satu, dia salah satu tokoh yang membidani lahirnya Aksera lalu DKS (Dewan Kesenian Surabaya). Dalam hal ini Amang sangat terlibat dalam kelembagaan, pengembangan infrastruktur dewan kesenian dan juga dalam pendidikan. Kedua, ia adalah tonggak dalam hal 
penciptaan seni. Karyanya mempunyai aura estetik yang khas, gabungan dari cita rasa Amang sebagai seorang muslim dan sebagai pelukis modern, dengan kecenderungan surealistik, serta wawasannya sebagai seorang yang terus melakukan pencarian estetik. ${ }^{10}$ Sementara di sisi yang lain, Amang juga dianggap bagian dari arus besar seni rupa Indonesia yang disebut dengan Lirisisme Humanisme Universal. ${ }^{11}$

Abdul Hadi juga mencatat, Amang Rahman adalah figur sederhana yang berpenampilan layaknya seorang faqir, senantiasa banyak senyum, juga seorang yang humoris dan akrab kepada setiap orang. Sebagai pelukis ia menyerap kebudayaan Islam, seni kaligrafi dan bentuk-bentuk seni Islam lain yang berkembang luas di pulau Madura, dan mengubahsuaikannya menjadi sarana pengucapan estetik bermutu tinggi. Obyek-obyek lukisannya menjadi bentuk yang hidup dan bergerak di alam penuh rahasia, yaitu alam tafakur. Lukisannya menampilkan suasana bayangan dari tatanan alam kerohanian, atau alam malakut sebagaimana disebut Imam al-Ghazali. ${ }^{12}$ Dalam hal ini Amang Rahman dianggap sebagai salah seorang pelukis modern Islami yang karyakaryanya mewakili kecenderungan surealistik (sufistik) yang unik. Kaligrafinya terasa lebih berupa sosok bentuk yang melayang, tidak seperti lazimnya tulisan yang terasa ditulis dan mengalir. ${ }^{13}$

\section{Konsep Estetika Amang Rahman}

Secara estetik Amang Rahman memiliki konsep kesenian yang disebutnya "Jamal, Kamal, dan Jalal". Ini mewakili apa yang disebut oleh kritikus Mamannoor. ${ }^{14}$ kesatuan semesta dirinya sebagai wujud mikro dan semesta raya (jagat raga dan jagat nir-raga) sebagai wujud makro. Kebertautan mikro dan makro ini bergulat dalam wilayah kreatif kesenian untuk diorientasikan kepada tata keberaturan (kosmos). ${ }^{15}$

10 Wawancara Djatiprambudi, 24 Mei 2016

${ }^{11}$ Wawancara Burhan, 23 April 2016

12 Abdul Hadi W.M, Islam, Cakarawala Estetik Dan Budaya (Jakarta: Pustaka Firdaus, 2000). hlm. 416-420

13 A.D. Pirous, Melukis Itu Menulis (Bandung: Yayasan Serambi Pirous dan Penerbit ITB, 2003). hlm. 133.

${ }^{14}$ Nurcahyo and Mamannoor, Ambang Cakrawala. hlm. 39

${ }^{15}$ Dalam terminologi tasawuf Ibn 'Arabi disebutkan, al-jamâl (keindahan) adalah pengalaman penyingkapan (kasyf) pertama dalam pengetahuan-diri (ma'rifah) akan wujud ketuhanan. Ini menjelaskan hadis yang masybûr di kalangan ahli tasawuf, "man 'arafa nafsahu faqad 'arafa rabbahu" (orang yang telah mengenal dirinya telah mengenal Tuhannya). Sedangkan al-jalâl (keagungan) merupakan pengalaman tahap kedua, atau berikutnya sesudah pengalaman akan keindahan. Mereka yang telah dibelalakkan penyingkapan kedua akan meraih al-kamâl (kesempurnaan). Ibn 
Amang sendiri menjelaskan konsepnya ini sebagai berikut: Jamal adalah keindahan yang mendalam, selain yang terkait dengan unsur-unsur visual seperti garis, bidang dan warna, dalam keseluruhan karyanya. Sesuatu yang mengarah atau menyentuh ke dasar psikologis orang yang melihat lukisannya. Kamal adalah sempurna, atau kesempurnaan tatanan manusia yang terefleksikan melalui karyanya. Dan Jalal, keagungan dalam kaitan penyerapan subyek terhadap obyek yang dilihat, baik itu lukisan itu sendiri maupun keagungan yang tampak dalam semesta yang menginspirasikan seniman untuk melukiskannya, Ketiga hal ini, menurut Amang, adalah tahapan-tahapan atau jenjang-jenjang dalam proses keseniannya. Dari mengamati yang indah (jamâl) seniman atau apresian menyadari kesempurnaan (kamâl) yang lebih jauh membawanya pada pengalaman akan keagungan (jalâh), dalam hubungan subyek-obyek seni rupa. Dalam bahasa yang sederhana konsep-konsep ini diterjemahkannya lagi menjadi "Keringat, Darah dan Air Mata". Bahwa, karya seni yang baik itu menurutnya haruslah menghimpun ketiga unsur ini. Lahir melalui perjuangan (keringat), gairah atau semangat yang tinggi, dan memunculkan keharuan di hati orang yang melihat hasilnya. ${ }^{16}$

\section{Karya-karya Seni Lukis Amang Rahman Jubair}

Lukisan Amang secara umum bernuansa surealistik, terutama melalui figur-figurnya yang lebih banyak simbolik. Namun demikian, surealisme Amang berbeda secara mendasar dengan surealisme mainstream yang berangkat dari alam mimpi

atau dunia bawah sadar melalui imaji-imaji yang mencekam. Sebaliknya, karya Amang justru menyajikan kesadaran tertinggi sebagai manusia, yaitu kesadaran religius-yang memancarkan kekuatan spiritual atau rohani. ${ }^{17}$

Dalam penelitian ini, karya-karya Amang Rahman setidaknya bisa ditelusuri dari sejak tahun 1968 hingga, yang terakhir, tahun 2000. Berdasarkan pengelompokan umum oleh para pengamat seni rupa, karya-karya seni lukis

'Arabi secara tegas menyebut pengalaman semacam ini sebagai suatu kesadaran di dalam Sang Mutlak, yang bagi sebagian sufi yang belum mencapai pemahaman ini (yang juga disebut sebagai kalangan mistikus yang tidak sempurna) mereka tidak menyadari hakikat sejati Kehadiran ini (Izutsu, 2015: 50-51).

${ }^{16}$ Sudarmanto, Tinjauan Seni Lukis Amang Rabman Jubair Periode Tahun 1990- 1993, Skripsi tidak diterbitkan (Fakultas Pendidikan Bahasa dan Seni, IKIP Surabaya, Surabaya, 1994). hlm. 124126

17 Abdul Hadi W.M, “Amang Rachman: Antara Surealisme Dan Sufisme," Berita Buana, Nopember 1984; Abdul Hadi W.M, "Amang Rahman: Pelukis Surealisme Sufistik Dan Kaligrafi," Media Indonesia, April 25, 1990. 
Amang Rahman Jubair dibagi dalam kelompok karya kaligrafi dan karya nonkaligrafi atau figuratif.

\section{a. Karya Kaligrafi}

Karya-karya kaligrafi Amang Rahman umumnya tidak mengikuti standar (kaidah) penulisan kaligrafi yang umum, seperti Naskhi, Tsulutsi, Farisi, Diwani, dst. Ia membuat sendiri khat atau gaya tulisannya, dan karena itu dianggap unik. Meski begitu, bukan berarti ia tidak menguasai kaidah-kaidah dasar tersebut. Karena penguasaannya terhadap bentuk kaligrafi-lah, seperti dikatakan Mamannoor, mudah bagi Amang untuk mengembangkannya melalui pengucapan dekoratif. Ia dengan cerdik menarik kepanjangan garis-garis bentuk kaligrafi bagian atas maupun lekukan bagian bawah menjadi unsurunsur yang plastis. ${ }^{18}$

Abdul Hadi menyatakan latar belakang (Islam pesisiran) Madura yang pernah diakrabinya, yang kaya dengan khazanah seni rupa Islam-seperti terlihat melalui ragam hias dan motif seni ukir, seni batik, lukisan kaca dan seni pahat pada batu nisan, serta ornamen arsitekturnya-membuat Amang Rahman begitu mencintai kaligrafi serta mengkreasikannya menjadi sarana pengucapan estetik bermutu tinggi. ${ }^{19}$ Dalam konteks yang demikian pula Amang pernah menyatakan:

Pada awalnya aku pernah mengunjungi sebuah masjid di Bangkalan, Madura; di situ aku mengamati arkeologi atau peninggalan sejarah yang unik. Aku sering pula pergi ke lokasi makam di berbagai tempat. Ada batu nisan yang selalu diubah bentuknya setiap periode. Kebetulan aku menguasai tulisan Arab, maka jadilah perhatianku tertuju membuat lukisan kaligrafi... Pada kaligrafi tidak sekadar berhenti pada elemen seni rupa misalnya bentuk, garis, warna maupun komposisi seperti lazimnya lukisan biasa. Kaligrafi mengekspresikan kata yang mengandung makna semacam wahyu yang bertitik tolak dari kitab suci Islam. ${ }^{20}$

Ciri-ciri lukisan kaligrafi Amang Rahman, menurut Mustofa Bisri, dapat disimpulkan dalam satu kata, yaitu "alami". Ia lebih mengikuti nalurinya ketimbang mengindahkan pertimbangan-pertimbangan yang lain, yang bersifat artistik. Sebagai pelukis muslim yang begitu intens mencari dan menghayati

\footnotetext{
${ }^{18}$ Nurcahyo and Mamannoor, Ambang Cakrawala. hlm. 54-55

${ }^{19}$ Hadi W.M, Islam, Cakarawala Estetik Dan Budaya. hlm. 417-418

20 Abdul Hadi W.M, "Pelukis Amang Rahman Dalam 'Diam' Menuju Puncak Estetika," Jayakarta, September 8, 1988.
} 
agamanya, naluri keindahannya selalu menuntun Amang kepada penuangan keindahan Islami sebagaimana yang ia rasakan. Dan sebagaimana Abdul Hadi, Mustofa Bisri sepakat bahwa kelebihan lukisan kaligrafi Amang adalah unsur tulisan yang tidak terkesan tempelan belaka. Ia menyatu dalam lukisannya, dengan nuansa mistis yang kuat.

Tema (isi) kaligrafi Amang umumnya merupakan do'a, lafazh dzikir (asma' Allah), dan potongan ayat atau surah di dalam al-Qur'an maupun hadis, juga hikmah kaum sufi (baik berupa doa maupun kata-kata mutiara). Umumnya ia memilih ayat-ayat atau kalimat-kalimat yang bersifat teduh, sebagai ibadah dirinya ataupun demi penyadaran bagi orang lain serta medium untuk mengingat kalam-kalam ilahi. ${ }^{21}$ Salah satu surah yang paling sering dilukis ulang olehnya, misalnya, adalah surah al-Ikhlas. Ini seperti memberi tekanan pada penghayatan Amang terhadap keberadaan sang Khalik.

Lafazh dzikir yang paling sering dilukis ulang oleh Amang, selain "Yâ Allah", adalah "Yâ Rạmân Yâ Rahîm (wahai Yang Maha Pengasih Yang Penyayang)", juga "Yâ Tawwấb Yâ Tawwâb (wahai Yang Maha Pengampun [diulang dua kali])". Adapun do'a yang dilukis Amang adalah do'a umumnya yang sering dibaca, seperti do'a sapu jagat (rabbanâ âtina fi al-dunyâ basanah, dst) dan do'a Nabi Ibrahim (rabbanâ hablanâ min ažnâjinâ, dst). Syair sufi terkenal, Abu Nuwas, (ilâhî lastu lilfirdausi ablan, dst) juga merupakan salah satu do'a yang pernah dilukisnya. Lukisannya yang paling monumental adalah sebuah lukisan dengan ukuran cukup besar $(100 \mathrm{X} 200 \mathrm{~cm})$, yaitu Do'a Akasyah. Potongan do'a pada lukisan itu adalah sebagai berikut:

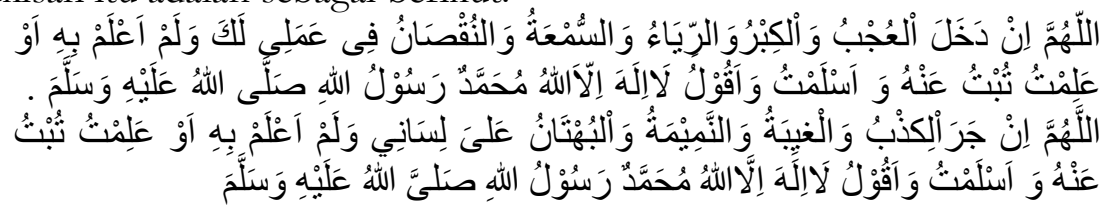

(Ya Allah, seandainya rasa sombong, takabur, riya' dan sum'ah, dan kekurangan di dalam amal perbuatanku bagi Engkau masuk ke dalam hatiku, sedang aku tidak mengerti atau mengerti, maka aku bertaubat dan berserah diri dengan mengucap "Lâ ilâha illAllah Mubammadur Rasulullab Saw". Ya Allah, seandainya sifat dusta, pengumpat, mengadu domba dan pembohong berjalan pada mulutku, sedang aku tidak mengerti atau mengerti, maka aku

\footnotetext{
${ }^{21}$ Nurcahyo and Mamannoor, Ambang Cakrawala.
} 
bertaubat dan berserah diri dengan mengucap "Lâ ilâha illAllah Mubammadur Rasulullah Saw”.)

b. Karya Non-Kaligrafi (Figuratif)

Sifat personal yang merupakan dunia batin Amang banyak menggambarkan lingkungan terdekatnya, pengalaman yang amat pribadi, keluarganya, maupun kenangan-kenangan yang terkait dengan masa kecilnya. Semuanya itu diwakilkan dalam bentuk-bentuk figuratif, dalam tema potret diri, keluarga, wanita, permainan anak, dan figurasi yang memiliki makna simbolik (akan dijelaskan dalam bagian analisis). Figurasi simbolik ini bisa disebutkan, antara lain, rembulan, lobang hitam, awan, gunung atau gunungan (pohon hayat), dan kuda.

Terkait warna dalam lukisannya, perlu dijelaskan, Amang sering menyebut warna surga. Yang dimaksud, adalah warna hijau kebiru-biruan. Ini merefleksikan kenangannya sekaligus visi sufistiknya tentang surga. Pada waktu kecil ia pernah diceritakan tentang warna surga, yang menurut kakeknya hijaunya tidak seperti warna rerumputan dan birunya tidak seperti warna Laut Kamal (di Madura). Dalam hal visi, M. Shoim Anwar (penyair dan cerpenis dari Jawa Timur) pernah menulis tentang warna surga Amang ini:

Hampir semua lukisan Amang Rahman, terutama setelah menginjak tahun '70-an hingga sekarang, sangat didominasi oleh warna hijau kebiru-biruan, ditambah paduan warna kuning, putih, merah, dan sedikit cokelat.... Soal warna di surga itu perhatikan ayat berikut ini: "Mereka itulah (orang-orang yang) bagi mereka surga 'Adn, mengalir sungai-sungai di bawahnya; dalam surga itu mereka dibiasi dengan gelang emas dan mereka memakai pakaian bijau dari sutera halus dan sutera tebal, sedang mereka duduk sambil bersandar di atas dipan-dipan yang indah. Itulah pahala yang sebaik-baiknya, dan tempat istirahat yang indah." (Qur'an, surat Al-Kahfi 31) 22

Dari ayat ini ternyata, kata Anwar, warna bagi Amang bukan sekadar hal yang kebetulan dan merupakan pilihan yang bersifat estetik semata, namun lebih jauh merupakan merupakan refleksi dari ayat-ayat transenden yang langsung dirujuk dari kitab suci. Warna hijau sebagai warna yang dipakai di dalam surga ini juga terdapat dalam QS. al-Rahman: 76 dan QS. al-Insan: 21, selain juga dikatakan dalam beberapa hadis.

\section{Tinjauan Estetika Sufi}

a. Imajinasi dan Kosmologi

\footnotetext{
${ }^{22}$ Robert Frager, Psikologi Sufi: Untuk. Transformasi Hati, Jiwa, Dan Rub (Jakarta: Zaman, 2014).
} 
Dalam sains Barat, psikologi membedakan imajinasi, halusinasi dan fantasi, sebagai gambaran mental yang ada di dalam pikiran. Imajinasi yang "diolah" lebih jauh menghasilkan fantasi, sedangkan imajinasi yang lahir dari kondisi psikis yang "sakit" biasa disebut sebagai halusinasi atau delusi. Robert Frager (Syekh Ragip al-Jerrahi) membandingkan antara psikologi Barat dan psikologi sufi, ia menyatakan, psikologi modern mengasumsikan bahwa alam semesta secara keseluruhan bersifat materi dan tanpa makna ataupun tujuan. Sedangkan menurut para sufi alam semesta diciptakan berdasarkan kehendak Tuhan dan merupakan cermin kehadiran-Nya. Psikologi berasumsi bahwa manusia tidak lebih dari tubuh, dan pikiran berkembang dari sistem saraf tubuh. Sementara dalam psikologi sufi, hati spiritual menjadi elemen penting sebagai tempat intuisi batiniah, pemahaman dan kearifan. Manusia lebih dari sekadar tubuh dan pikiran. Ia merupakan perwujudan ruh Ilahi. Menurut psikologi Barat puncak kesadaran adalah kesadaran rasional, sedang sufisme menunjukkan bahwa, bagi kebanyakan manusia, kesadaran rasional merupakan kondisi "tidur dalam sadar". ${ }^{23}$

Dalam lukisan "Tafakur" (1987), misalnya, melalui pengulangan bentuk, yang mudah sekali memancing asosiasi kepada citra surealistik, memperlihatkan ruang berbilang dan simbolik, atau semacam fantasi yang menampilkan kesunyian yang damai dan keheningan kontemplasi. Figur tak sempurna (dalam detail wajah, jemari tangan maupun kaki) yang tampak bersemedi dibuat berulang makin menjauh ke belakang sebanyak empat kali. Pada setiap figur tampak bentuk bulatan cahaya yang membungkus kepalanya. Repetisi figur itu sendiri membuat citra ruang yang berlapis dan makin jauh, persis seperti lukisan "Impresi Sebuah Lagu" (1992), yang menurut Jim Supangkat (kritikus seni rupa Indonesia) menggaungkan bunyi. Di sisi kanan figur yang berulang ada satu lagi figur yang serupa, tampak duduk di atas bulatan cahaya dan di atasnya bentuk piramida yang berlapis tujuh yang dikelilingi cahaya yang berlapis-lapis pula. Secara keseluruhan lukisan ini dibalut warna gelap yang tak menjelaskan lanskap apa dan bagaimana kecuali dua pertiganya dibagi oleh garis cakrawala yang di atasnya ada awan berbaris. Figur orang dalam posisi duduk bersemedi dibuat kembali sebagai obyek pada lukisan "Piramid" (1991). Dalam lukisan ini dilukiskan lima figur duduk tafakur yang dilingkupi cahaya berbentuk piramida.

Suhrawardi adalah sufi pertama yang berbicara tentang dunia imajinal secara mikrokosmik. Ia kemudian diikuti oleh Ibn 'Arabi yang mengelaborasi

${ }^{23}$ Ibid. hlm. 36-39 
tema ini, dan memperluas pemahaman tentang dunia imajinal dengan menjadikannya sebagai pilar utama metafisikanya. Dari sini, dunia imajinal menjadi bagian dan bidang pemahaman tentang alam Islami yang tentangnya banyak sekali sufi dan filosof menulis risalah penting. Mulla Shadra kemudian memberikan penjelasan sistematis dan filosofis mengenai dunia imajinal ini, terutama yang berkaitan dengan realitas makrokosmos yang mandiri dan terpisah dari manusia (khayal al-munfashil). Menurutnya, dunia imajinal ini bahkan mempunyai realitas lebih besar dari dunia fisik, ia merupakan dunia yang memiliki bentuk-bentuk imajinal (al-shuwar al-khayâliyyah) yang tidak terkait dengan materi, atau paling tidak bukan materi dari dunia fisik. Bentuk-bentuk itu disebut "al-mutsûl al-mu'allaqab" (bentuk-bentuk yang menggantung), yang memiliki warna, bentuk dan bau, yang berkaitan dengan bentuk-bentuk dunia ini. Realitasnya sama kongkret dengan dunia yang kita diami, namun tidak persis sama. Dikatakan, ini adalah dunia tempat kita mempunyai raga-raga halus (subtil) atau imajinal (al-jism al-khayali) sebagaimana kita mempunyai raga fisik di dunia sekarang ini. ${ }^{24}$

Dalam lukisan Amang, bentuk-bentuk yang "menggantung" itu bisa dilihat dalam hampir semua latar obyek lukisannya dan dalam lukisan kaligrafinya-yang dikatakan Pirous huruf-hurufnya seperti melayang-layang. Bahkan, termasuk dalam cara Amang membuat potret dirinya yang tak sempurna, yang menunjukkan dirinya secara umum namun itu bukan dirinyakarena pemirsa seakan melihat diri Amang yang lain dalam potret dirinya.

Pandangan para sufi sendiri terhadap makrokosmos yang melingkupinya memperlihatkan suatu dunia yang berlapis-lapis, tidak terbatas pada yang dapat dilihat saja. Pandangan Ibn 'Arabi misalnya, yang secara kontroversial dipahami sebagai wabldatul wujûd, membedakan tiga bentuk wujud: yang mutlak (Tuhan itu sendiri), yang mumkin (kontingen) atau tergantung pada yang mutlak, dan yang bukan eksis (wujud) dan bukan pula non-eksis ('adam)bukan abadi dan bukan pula temporer (eksistensi Nur-Mubammad); di mana dua yang terakhir ini pun pada dasarnya merupakan bentuk pancaran atau penampakan diri (tajalli) dari Tuhan yang mutlak itu sendiri (lihat Ali, 2002: 6369). Ibn 'Arabi, al-Jilli, dan al-Burhanpuri dalam konsep tajalli Tuhan membagi tingkatan alam ke dalam tiga, lima, dan tujuh tingkatan (lihat Miftah Arifin, 2015). Konsep semacam ini juga disebut sebagai marâtib al-wnjûd, yang di

${ }^{24}$ Nasr, Spiritualitas Dan Seni Islam. 
antaranya oleh al-jilli dipaparkan dalam beberapa martabat: Ulubiyah, Ahadiyah, Wabidiyah, Rahmaniyah, dan Rububiyah. ${ }^{25}$

Dalam paradigma yang demikian, para sufi melihat realitas yang tampak maupun yang tak tampak sebagai wujud kehadiran Tuhan dalam keseluruhannya. Realitas-realitas yang ada menjadi cermin dari keberadaan dan kehendak Tuhan semata. Dalam lukisan-lukisan Amang sap atau jenjang itu bisa dibuatnya lima, seperti pada lukisan "Salamun Qaulan Min Rabbir Rahim" dan "Impresi Lasem II", atau tujuh seperti pada "Meditasi" dan "Lalu Kudekap Dia". Saf-saf itu dalam visualisasinya berupa tepi outline (garis) dalam bentuk lengkungan, baik di atas cakrawala maupun yang dibuat secara surealistik melayang-layang serupa gelombang di atas kepala.

Hampir dalam semua lukisan Amang, obyek-obyeknya dilingkupi ruang semesta yang kosong dan gelap yang bergradasi dalam irama gelombang awan atau lapis-lapis batas yang tegas namun abstrak. Manusia, figur-figur simbolik, gunung maupun daratan yang luas selalu dilingkupi atau diliputi oleh misteri, sesuatu yang abstrak, yang mengindikasikan ketidakmampuan manusia untuk mengamati kehidupan secara keseluruhan. Ketika melukiskan kesannya terhadap pemandangan Lasem, sebuah kota di Jawa Tengah yang merupakan tempat tinggal sahabatnya Mustafa Bisri yang sering dikunjunginya, dalam "Impresi Lasem I" (2000), Amang menggambarkannya dalam bentuk perbukitan dan matahari jingga yang terbenam dalam abstraksi warna kebiruan yang tak jelas mana laut dan langit, kecuali yang dapat teridentifikasikan melalui batas cakrawala yang tegas. ${ }^{26}$

b. Tradisi

Tradisi dalam pengertian Nasr menyiratkan sesuatu yang sakral, disampaikan kepada manusia melalui wahyu maupun pengungkapan yang bersifat transendental. Hal ini kemudian diteruskan secara horisontal dan berkesinambungan dalam mata-rantai vertikal yang menghubungkan setiap denyut kehidupan tradisi yang bertalian dan bersumber pada realitas transenden yang bersifat meta-historikal atau perennial. Terutama melalui sumber-sumber al-Quran dan Hadis, di dalam Islam, serta apa yang disebut sebagai "al-Barakah al-Mubammadiyab". Barakah yang dimaksud, adalah realitas spiritual substansi

\footnotetext{
${ }^{25}$ Miftah Arifin, Wujudiyah Di Nusantara: Kontinuitas Dan Perubaban (Jember: STAIN Jember Press bekerjasama dengan Pustaka Pelajar, 2015). hlm. 41

${ }^{26}$ Garis cakrawala sendiri, menurut Mamannoor, merupakan bagian penting dalam lukisan Amang. Amang mengatakan, "cakrawala itu ibarat garis batas yang diam dan sunyi, namun di bawah dan di atas cakrawala ada gerak.
} 
jiwa Nabi yang tidak sekadar meliputi hadits dan sunnabnya, tapi juga melalui jalan yang tak dapat diraba di dalam hati mereka yang terus mencari Tuhan, yang napasnya terus meniupkan keberkahan Nama-Nya. ${ }^{27}$

Sejauh menyangkut seni, kata Nasr, Islam tradisional mempertahankan suatu bentuk "islami" seni Islam yang berkaitan dengan aspek batin dan spiritual agama, dalam bentuknya yang tampak (rupa) maupun yang terdengar (suara). Dengan demikian, agama tidak hanya mempunyai satu kebenaran tetapi juga (mengungkapkan) suatu kehadiran, dan barakah yang memancar dari seni Islam merupakan suatu esensi, sama esensialnya dengan syariah bagi kelangsungan hidup agama. ${ }^{28}$

Pada tahun 1970 Amang sebenarnya sudah membuat sebuah lukisan yang berkecenderungan pada aksara Arab, melalui lukisan berjudul "Simbol Purba II", yang menampilkan semacam bentuk rajah atau wafak. ${ }^{29}$ Lukisan dengan latar sederhana berwarna kecoklatan ini menampilkan satu bentuk simbolik lingkaran yang di dalamnya ada lingkaran lebih kecil. Antara lingkaran besar dan lingkaran kecil di dalamnya diberi garis-garis penyekat bidang, dan di dalam sekat-sekat bidang itu diisi dengan aksara Arab ج di dalam lingkaran kecil dan pada sekat bidang yang paling besar, serta s pada bidang yang lebih kecil lagi. Latar belakang, atau di sisi luar lingkaran, diisi dengan gradasi warna merah dan kecoklatan yang makin gelap ke arah luar (tepi kanvas). Di sisi sebelah kanan lingkaran ada torehan garis (bidang kecil memanjang) berwarna merah yang cukup kuat dengan garis batas yang tegas. Dengan komposisi dan abstraksi demikian, ditambah simbolisasi huruf, lukisan ini sangat mengesankan secara spiritual.

Simbolisme huruf sendiri merupakan citraan yang bersifat mistik dan dianggap penting dalam tradisi sufi. Setiap muslim mengakui pentingnya abjad Arab, yakni huruf-huruf yang digunakan untuk mengungkapkan sabda abadi alQur'an. Melalui Q.S. Al-Kahfi: 109, yang sering diulang-ulang kaum sufi, digambarkan keagungan, keindahan dan kesempurnaan ilahi. Semua nama dan sifat Allah hanya bisa diungkapkan dengan menggunakan huruf-huruf ini,

\footnotetext{
${ }^{27}$ Nasr, Spiritualitas Dan Seni Islam. hlm. 3 dan 17.

${ }^{28}$ Ibid. hlm. 6.

${ }^{29}$ Penulis tidak menemukan pernyataan dari orang-orang terdekatnya, apakah Amang pernah mempelajari hal-hal yang berkaitan dengan penulisan rajah yang sangat terkait dengan aspek mistik tasawuf Islam ini. Namun, jika ditelusuri dari kesenangannya mengamati bentuk-bentuk nisan (dan yang tertera di atasnya) maupun bentuk artistik simbolik lainnya, bisa jadi ia tertarik secara artistik belaka pada bentuk simbolik ini.
} 
namun huruf sendiri menampilkan sesuatu yang berbeda dari (bukan) Allah. Huruf-huruf itu merupakan suatu cadar ke-yang-lain-an yang harus diterobos oleh ahli mistik, dan seperti dikatakan Niffari, selama masih terikat pada hurufhuruf itu si ahli mistik bisa dikatakan memuja berhala (Shcimmel, 2009: 519). Huruf ج (dibuat dua kali) dan dalam lukisan Amang berdiri secara sendirisendiri dan tidak membentuk makna/ kalimat, seperti umumnya terdapat dalam bentuk wafak. Wafak sendiri merupakan simbolisme huruf dan angka (Arab) yang disusun berdasarkan keahlian mistik untuk suatu kegunaan tertentu. Simbolisme tersebut dalam lukisan dikuatkan abstraksi warna dan latar yang mengesankan kosmos "yang-lain".

Salah satu puncak karya kaligrafi Amang Rahman adalah yang terekspresikan melalui lukisan "Sebahagian Doa Akasyah". Karya ini secara tradisional tidak hanya merepresentasikan seni tradisional Islam melalui bentuk kaligrafi, namun juga diambil dari khazanah tradisi tasawuf. Doa ini cukup terkenal di kalangan ahli tasawuf, sebagai bentuk doa yang indah secara sastrawi maupun secara "emosional". Amang terutama mengutip bagian yang paling menyentuh, terkait kesadaran keberserahan diri yang total di hadapan Tuhan, dari doa yang sebenarnya relatif panjang ini: "seandainya rasa sombong..., seandainya sifat dusta..., maka aku bertaubat dan berserah diri dengan mengucap "Laa ilaha illAllah Mubammadur Rasulullah Saw." Lukisan ini sepenuhnya diisi kaligrafi (kutipan Do'a 'Akasyah), tak ada bentuk lain kecuali arakan awan tipis di sisi kirinyayang kata Amang melambangkan gerak. Warna dominan biru dan bentuk kaligrafinya yang monumental difokuskan pada tulisan "Lâ ilâha illa Allâh Muhammad al-rasul Allâh" menggambarkan keadaan mental yang pasrah dalam persaksian akan keagungan Allah dan kebenaran risalah Nabi-Nya, dan betapa rendahnya diri di hadapan-Nya.

c. Simbol dan Pengalaman Spiritual

Bahasa simbolis dan figuratif menjadi kunci untuk membuka makna yang tersembunyi di antara prinsip dan fenomena, serta korespondensi dan pertalian antara wujud rendah dengan wujud yang lebih tinggi. Hal ini tidak harus terkesan mewah (spektakuler dan detail seperti pada lukisan-lukisan surealistik Salvador Dali, misalnya), karena pada dasarnya bahasa simbol dan ilham spiritual yang menyertainya menyajikan nutrisi yang vital bagi hati dan jiwa. Sebagaimana dalam al-Qur'an juga, berbagai jenis simbolisme dan penggambaran tak lain merupakan bahasa figuratif dan kiasan yang digunakan secara spiritual. 
Di bawah ini akan dijelaskan beberapa simbol dalam lukisan Amang yang berkaitan dengan dunia tasawuf.

1. Simbol Rembulan

Rembulan kuning dalam lukisan "Potret Diri" (1996) adalah harapan akan kesempurnaan dari figur Amang yang dilukis pipih seperti bentuk wayang di sisinya, seolah dirinya sendiri adalah bayang-bayang dari kesempurnaan yang diharapkannya itu. Dirinya yang tua dan penuh lobang, atau katakanlah penuh dosa, di dadanya yang serupa seruling merindukan seseorang yang dapat meniupnya dengan nada merdu. Warna hijau dan biru yang dominan pada pakaian dan latar belakang seperti menarik kita ke alam lain yang sakral, yang puncak kerinduannya ada pada rembulan kuning yang di dalamnya terasa ada alam lain lagi yang lebih agung dan sakral. Rembulan kuning dalam lukisan ini terasa penuh secara spiritual.

Bulan penuh atau purnama dalam syair-syair mistik seringkali dikaitkan dengan kesempurnaan figur Nabi Saw sebagai insan kamil (manusia yang paling sempurna). Tidak hanya melalui bulan purnama (badrun), Nabi juga sering dimetaforakan sebagai matahari (syamsun), lilin penerang, dan pelita bercahaya (sirâjan munira). Ungkapan terakhir ini, yang menjadi semacam protoype "cahaya Muhammad" dalam mistifikasi sesudahnya, diambil oleh Hassan ibn Tsabit dari al-Qur'an. Hassan menggambarkan Nabi Muhammad sebagai seseorang yang membawa cahaya dan kebenaran dalam kegelapan (seperti dalam QS. 5:15). Lebih jauh, dalam menggambarkan perang Badar, ia menyebut wajah Nabi bersinar bagaikan bulan purnama (badrun). Muqatil, seorang teolog Islam abad ke-6 M, adalah yang pertama menafsirkan kata-kata (terutama kata mishbah [pelita]) dalam QS. 24:35 (Allahu nûrussamâwâti wal ardh... al-mishbâhu u fi zujajjah....) yang mengacu kepada Nabi. Dari tafsiran Muqatil inilah teori-teori tentang karakter Nabi yang bercahaya mulai berkembang pada paruh-kedua abad ke-9 M, dan Sahl al-Tustari (seorang sufi yang wafat pada tahun 896 M) mengembangkannya lebih jauh-yang menghubung-tafsirkan surah an-Najm (QS. 53) dengan Cahaya Muhammad. Murid Sahl, al-Hallaj, menyatakan secara puitis dalam "Thasin al-Siraj" bahwa Nabi adalah sebuah lampu dari cahaya Yang Mahagaib, sebuah bulan yang bercahaya di antara bulan-bulan lainnya. Kemudian, Ibn 'Arabi-lah yang terutama bertanggung jawab atas peran pokok cahaya ini dalam ajaran sufi selanjutnya. ${ }^{30}$

\footnotetext{
${ }^{30}$ Annemarie Schimmel, Dan Mubammad Utusan Allah, Cahaya Purnama Kekasih Tuhan (Bandung: Mizan, 2012), hlm 180-207.
} 
Simbol bulan, baik yang berbentuk penuh maupun sebagian, menjadi obyek yang signifikan dalam lukisan Amang. Selain melalui dua lukisan yang telah dijelaskan di atas, rembulan kuning hadir dalam lukisan terdini pada tahun 1968, lukisan "Undangan" misalnya, hingga pada lukisan yang dibuat menjelang wafatnya, seperti pada "Impresi Lasem II" (2000). Makna keagungan atau kesempurnaan yang dirindukan itu bagi Amang harus didekap erat, seperti tergambar melalui lukisan "Lalu Kudekap Dia". Pada yang terakhir ini, Amang membagi lukisan ke dalam tiga bagian secara vertikal— tanah pijakan tempat ia duduk bersemedi, dirinya yang mendekap erat bulatan berwarna kuning dan dilingkupi cahaya keagungan serupa gunung, serta bulan purnama di atasnyasemuanya "dibalut" keagungan warna surga yang menjadi latarnya. Di bawah figur Amang yang duduk bersemedi ada semacam bentuk bola bumi separuh berlapis dua. Terkesan sangat mistis, lukisan ini seperti ingin mengungkapkan pernyataan "cahaya di atas cahaya (nûrun 'alâ nûr)". Ini semacam bentuk kontemplasi (musyâhadah) akan kerinduan terhadap kesempurnaan pengetahuan, atau bisa juga kematian - seperti sering diungkapkannya dengan sangat biasa pada masa tuanya.

\section{Simbol Awan}

Awan putih yang membalut rembulan kuning pada lukisan "Alif Laam Mim" merefleksikan kehadiran barakah pada bulan yang dibalutnya. Awan yang serupa selimut itu tidak sekadar mengimbangi kegelapan di belakangnya secara visual, tapi benar-benar menghadirkan keagungan yang ada di baliknya. Terkait lukisan ini, menurut Wisetrotomo, makna ayat direpresentasikan Amang ke dalam kanvas dalam bentuk misteri-persis seperti tafsir ayat ini umumnya, "hanya Allah yang tahu maknanya". Secara umum ayat-ayat yang dikutip Amang Rahman seperti berada dalam ruang tanpa batas yang dibalut dengan gelombang putih awan. Ayat-ayat itu "dikembalikan"nya kepada asalnya, interpretasinya memiliki kekuatan memprovokasi kesadaran ketuhanan, kesadaran keilahian, kesadaran spiritualitas, agar berserah diri secara penuh kepadanya. ${ }^{31}$

Sedangkan awan yang seputih kapas di dalam lukisan "Pegunungan Cangar" benar-benar menyedot kita ke dalam nuansa penuh sakralitas di dalam keseluruhan abstraksi lanskap lukisan yang bersifat imajinatif itu. Perarakan awan dalam lukisan ini seperti dilihat dari ketinggian di atasnya. Dalam hal ini Nurcahyo memberi catatan, terjadi pergeseran makna simbolik dalam orientasi

31 Suwarno Wisetrotomo, Imaji Surga Biru Amang Rahman” Katalog Pameran Imaji Surga Biru Amang Rahman (Yayasan Kembang Jati, 2001). 
seni lukis Amang. Biasanya Amang menatap langit cukup dari depan rumahnya sambil berkhayal ke dunia antah-berantah, namun kini dunia seperti berada di bawah telapak kakinya. Kita seakan dibawa Amang melayang-layang di atas awan tanpa kengerian sama sekali, karena suasana lukisan ini sendiri melalui nuansa warna biru kehijau-hijauan terasa teduh dan nyaman (Nurcahyo: 1996).

Untuk menjelaskan makna simbolik awan dalam tradisi sufi, perlu dikemukakan sebuah hadis yang diriwayatkan Tirmidzi. Nabi pernah ditanya, di manakah Tuhan mewujud sebelum menciptakan makhluk? Nabi menjawab, "Dia berada di dalam awan ('amâ), tidak di atas tidak pula di bawah, dan tanpa udara". Ibn 'Arabi menerangkan arti kata 'amâ' dalam hadis ini sebagai "awan tipis yang berada di angkasa". Melalui awan, kosmos mengambil bentuk. Dikatakan, awan adalah imajinasi absolut karena ia memberi bentuk pada segala ciptaan. Awan juga nama lain untuk menyebut barzakh — selain nama lain seperti 'nafas rahmâni'. Barzakh sendiri merupakan alam imajinal, yang menengahi antara ruh yang murni spiritual dan jasad yang murni fisik. ${ }^{32}$ Sebagaimana barzakh, awan berada di sisi Tuhan dan "ketiadaan", serta memiliki sifat keduanya. Dalam hal ini, term "awan", sebagaimana halnya term "imajinasi", digunakan untuk menarik perhatian terhadap kefanaan segala ciptaan. ${ }^{33}$ Selain, terutama yang menonjol melalui dua karya di atas, bentuk awan hampir selalu ada setiap dalam lukisan Amang, yang kaligrafi maupun yang figuratif, yang menguatkan suasana surgawi pada karya-karyanya.

Untuk dapat membayangkan ruang yang maknanya melebihi ruang fisikal belaka, dan memahaminya melalui teknik dan simbolisme jenis suci tertentu—kata Nasr, harus ada pemisahan antara ruang yang diciptakan oleh seni ini dan ruang fisikal yang profan yang menjadi tempat tinggal manusia. Dalam miniatur Persia, misalnya, ketidakberdimensi-tiga-an (dalam perspektifnya yang tampak "kacau") ruang natural di sekitarnya secara kualitatif melukiskan tingkatan realitas. Hal ini dibayangkan mampu menuntun manusia dari horizon eksistensi material, dan juga kesadaran profan serta duniawi, ke tingkat keberadaan dan kesadaran yang lebih tinggi menuju dunia berikutnya, dengan ruang, waktu, gerakan, warna dan bentuk-bentuknya sendiri. Dikatakan, bahkan tumbuh-tumbuhan dan hewan-hewan yang digambarkan pun bukan begitu saja diambil dari alam fisikal, melainkan dari alam primordial surgawi

\footnotetext{
${ }^{32}$ Mujiburrahman, Agama, Media Dan Imajinasi: Pandangan Sufisme Dan Ilmu Sosial Kontemporer (Pidato Pengukuban Guru Besar Sosiologi Agama) (Banjarmasin: IAIN Antasari Press, 2015). hlm. 6. 33 William C. Chittik, The Sufi Path of Knowledge (Tuhan Sejati Dan Tuban-Tuban Palsu) (Yogyakarta: Qalam, 2001). hlm. 345-350
} 
yang ada di 'alam al-khayal. Demikian pula dengan warna gunung, awan atau langit yang unik dan berbeda dari warna-warna alamiah. ${ }^{34}$

3. Simbol Kuda

Lukisan "Perjalanan" (2000) terkesan sangat simbolik. Lukisan ini menggambarkan figur mirip Buraq dalam tradisi mistik Islam, meski tidak digambarkan sedetail gambar tradisional yang umumnya dikenal umat Islam. Makhluk berbadan kuda dengan kepala manusia ini digambarkan melintasi lapis-lapis daratan, yang digambarkan melalui batas atau outline linear berbukitbukit. Melihat arah dongak kepalanya, ia seperti tengah berlari menuju ke atas, di mana bulan separuh berwarna jingga terbit di atas cakrawala yang lebih tinggi. Penulis sendiri, meski tidak menemukan pernyataan langsung yang menjelaskan maksud lukisan ini, terpancing menghubungkannya dengan perjalanan Isra' dan Mi'raj Nabi Saw, atau setidaknya pelukis mengambil inspirasi lukisannya dari kisah yang terpatrikan di dalam al-Qur'an melalui surah al-Isra' ini. Secara simbolik tanda-tanda ikonik yang dikomposisikan dalam lukisan ini memungkinkan pemaknaan seperti itu: figur makhluk itu merujuk kepada Buraq, sedangkan rembulan jingga yang besar itu dirujukkan pada metaforisasi cahaya Nabi. Dan, kosmos yang melingkupinya mengesankan lapis-lapis alam imajinal yang dilintasi dalam perjalanan suci itu.

Schimmel menggambarkan Buraq, mengutip para penyair sufi-salah satunya Ghanizade dari Turki abad ke-17 M, sebagai seekor binatang berkaki empat yang lebih besar dari seekor keledai dan lebih kecil dari seekor kuda. Gambaran ini persis dengan yang dikatakan Nabi melalui hadis yang diriwayatkan Anas bin Malik, “... dan didatangkan kepadaku seekor binatang [putih] bukan bughal (peranakan kuda dan keledai) dan lebih besar daripada keledai (yaitu Burak)".35 Para penyair lalu menambahkan gambaran makhluk ini: diciptakan dari cahaya, dengan kepala seorang wanita dan ekor burung merak, yang dengan cepat membawa Nabi melewati bergalaksi-galaksi malaikat; tubuhnya bunga mawar, rambutnya byacinth (sejenis bunga), gagah perkasa dan mempesona; yang merupakan suatu gambaran tradisional yang terus hidup hingga sekarang di masyarakat muslim Asia. ${ }^{36}$

Dalam sebuah metafora sufi kuno, ada yang menyamakan ruh-ruh spiritual dengan sebuah kereta kuda. Ruh mineral adalah rangka dan as roda,

\footnotetext{
${ }^{34}$ Nasr, Spiritualitas Dan Seni Islam. hlm. 194-196

${ }^{35}$ Al-Imam Al-Bukhari, Shahîh Al-Bukhârî (Beirut: Dâr al-Kutub al-'Ilmiyah, 2009). hlm. 334

${ }^{36}$ Annemarie Schimmel, Dan Mubammad Utusan Allah, Cahaya Purnama Kekasib Tuban (Bandung: Mizan, 2012), hlm 246-249.
} 
ruh tumbuhan adalah badan kereta, ruh hewani adalah kudanya, dan ruh pribadi adalah pengendaranya; ruh insani dipadukan dengan ruh rahasia dan ruh maharahasia, adalah si pemilik yang duduk di dalam kereta kuda. ${ }^{37}$ Melalui metafora ruh hewani yang mengambil bentuk kuda ini kita dapat melihat karya dengan figur kuda Amang yang paling terdini, yang dibuatnya pada tahun 1968. Lukisan berjudul "Rembulan dan Matahari" (90x65 cm) ini menggambarkan obyek kuda dan bulatan sempurna berwarna kuning di atasnya. Bulatan ini, jika mengacu pada judul bisa berarti rembulan atau juga bisa matahari. Namun jika melihat pada latarnya berupa kosmos yang gelap, penulis lebih suka memaknainya rembulan, dan seperti disebutkan sebelumnya rembulan bisa bermakna kesempurnaan. Gestur tubuh kuda tampak seperti berlari menyongsong rembulan, dengan posisi "melingkari”"nya. Melalui lukisan yang dibuatnya pada masa awal-awal ia melukis ini, kita dapat melihat jejak spiritualitas Amang, sebagai pribadi rendah (bersifat) yang mengejar/ mencari kesempurnaan hidup.

4. Simbol Pohon Hayat

Gunungan atau pohon hayat diambil dari tradisi kebatinan Jawa yang diberikan penguatan makna sufistik. Kesadaran atas simbol ini juga bisa dimaknai sebagai ingatan akan asal-usul diri sekaligus puncak pencapaian yang diharapkan seorang sufi, yaitu kehadiran "al-barakah al-Mubammadiyab" yang merupakan manifestasi kasih sayang Allah terhadap alam semesta ini. Dalam bahasa Mamannoor, Amang juga menjaga vibrasi irama kehidupan yang dinyatakan melalui gambar pohon. Pohon hayat dan seruling jiwa itulah yang dijaga keberadaannya untuk keteduhan iman, seperti dimaknai Maman melalui lukisan "Pohon Kehidupan dan Dua Buah" (1993) dan "Pohon Hayat" (1996).

Ibn 'Arabi ketika membicarakan tentang hakikat penciptaan menyebut bahwa alam raya (kosmos) ini seluruhnya adalah Pohon (syajârat al-kauniyyah atau syajârat al-wujüd) yang tumbuh dari kata benih (kata) Kun. Tuhan adalah akar dan kita (makhluk) adalah cabang dari akar. Nama-nama Tuhan melekat pada pohon ini, dan kita identik dengan buahnya. Dari esensi (huruf) Kaf muncul dua makna yang berbeda, kamaliyyah (kesempurnaan) dan kufriyyah (keingkaran), sementara dari Nun muncul nun-nakirah (kekurangan/ ketidaktahuan) dan nun-ma'rifah (pengetahuan tentang Tuhan). Ketika ditampakkan kepada makhluk dari Kun ketiadaan pada hukum yang dikehendaki oleh keqadiman (kekekalan), maka Tuhan memercikkan cahaya dari Cahaya-Nya. Orang yang terkena cahaya tersebut, kata 'Arabi, ia kemudian

${ }^{37}$ Frager, Psikologi Sufi: Untuk Transformasi Hati, Jiwa, Dan Rub. hlm. 202. 
memandang gambaran 'Pohon Kejadian' (Syajârat al-Kaun) yang tumbuh dari benih Kun, ia akan mendapatkan kebahagiaan. Sedangkan orang yang tidak terkena cahaya, ia akan salah mengira bahwa huruf dari kata Kun adalah kufriyyah dan nakirah, karenanya ia termasuk kelompok orang-orang yang kafir (ingkar). ${ }^{38} \mathrm{Hal}$ ini dapat menjelaskan makna simbolik yang terdapat pada lukisan berikut ini.

Pada lukisan "Pohon Hayat" bentuk gunungan wayang diletakkan di tengah dalam komposisi 'balans simetris'. Di dalam gunungan wayang ini dilukis pohon kehidupan dengan tujuh lobang yang berderet ke atas seperti pada bentuk seruling, sementara di tangkainya yang menjuntai ke bawah menggantung dua buah berwarna orange. Di pucuk lancip gunungan membayang rembulan kuning yang di dalamnya dilukis saf berjumlah lima jenjang. Latar belakang dibagi tiga, dipisahkan garis cakrawala dan lengkung bumi di bawahnya. Komposisi lukisan yang simetris dan vertikal menyiratkan keagungan, sedangkan gerak daun yang menjuntai beserta tangkainya menyiratkan irama seperti ditiupkan dari seruling kesunyian jiwa pelukisnya. Seperti juga pada "Pohon Kehidupan dan Dua Buah", pohon hayat itu dua cabangnya yang menjuntai mengeluarkan dua buah berwarna merah. Ini menurut penulis melambangkan sifat kerendahan diri (berdosa), seperti dijelaskan makna kufriyyah dan nakirah di atas. Sementara pada lukisan yang lebih akhir, "Pohon Kehidupan dan Dua Bunga" (1997), lebih terasa ungkapan kebahagiaannya, di mana cabang-cabang pohon mengarah ke atas dan dua di antaranya yang paling tinggi mengeluarkan dua bunga berwarna putih seperti kapas. Ini bisa dimaknai, Amang telah mengatasi keingkaran dan kekurangannya dan bersiap menyongsong kesempurnaan (kamaliyyah) dan pengetahuan (ma'rifah) sifat-sifat ketuhanan dalam dirinya.

Akhirnya, perlu diungkapkan pernyataan Agus Dermawan T, bahwa "di dalam lukisan Amang terkandung penghayatan intens terhadap makna hidup. Ia beribadah dalam melukis, dan ia pun melukis sambil bertafakur dan berzikir, seperti berkhalwat". Dengan pernyataan ini dan melalui penjelasan dalam keseluruhan bab ini dapat dikatakan, lukisan-lukisan Amang Rahman Jubair memiliki ciri-ciri yang dekat dengan lukisan yang bersifat surealistik, meski begitu ia bukan merupakan bagian dari gerakan surealisme yang sekadar mengeksplorasi imajinasi dan fantasi sebagaimana dalam pengertian psikologi Barat. Keseluruhan tematik dan simbol-simbol dalam lukisan Amang

\footnotetext{
${ }^{38}$ Muhyiddin Ibnu 'Arabi, Misteri Kun: Syajaratul-Kaun (Surabaya: Risalah Gusti, 2005) hlm. 4-6; Chittik, The Sufi Path of Knowledge (Tuban Sejati Dan Tuban-Tuban Palsu), hlm 278.
} 
merupakan ekspresi dari pengalaman spiritual Amang yang bersifat transendental dan imanen. Ini terungkapkan dalam keutuhan gagasan seni lukisnya seperti telah ditinjau melalui pendekatan imajinasi dan kosmologi, tradisi serta simbol yang khas dan dekat dengan pemahaman kaum sufi. Hal ini hanya dimungkinkan oleh kesadaran mendalam terhadap kosmos yang merupakan representasi dari "kehadiran" Tuhan.

\section{Simpulan}

Melalui penelitian ini dapat disimpulkan bahwa:

1. Karya-karya Amang Rahman Jubair merepresentasikan spiritualitas kehidupannya. Antara corak lukisan dengan sikap hidup dan pandangan Amang keduanya saling berhubungan. Pencarian estetik seni rupa Amang membuatnya sampai pada kesadaran yang mendalam akan kehadiran Tuhan, dalam suatu kondisinya yang disebutnya hening dan bening.

2. Karya-karya seni lukis Amang Rahman Jubair merepresentasikan hal yang sakral atau suci. Adakalanya sebelum melukis ia merenung (berdzikir dan berdo'a) dalam suasana yang disebutnya hening dan bening. Bentuk-bentuk simbolik dalam lukisannya memancarkan barakah yang bagi pengamat lukisannya membawa kesadaran yang mendalam akan Tuhan. Simbol-simbol yang terdapat dalam lukisannya diambil dari tradisi atau khazanah yang lazim ada dalam sufisme.

\section{Daftar Pustaka}

Al-Bukhari, Al-Imam. Shahîh Al-Bukhârî. Beirut: Dâr al-Kutub al-'Ilmiyah, 2009.

Anwar, M. Shoim. "'Lukisan Non-Kaligrafi Amang Rahman Lebih Menggiring Ke Transendensi."” Surabaya Post, February 19, 1994.

Arifin, Miftah. Wujudiyah Di Nusantara: Kontinuitas Dan Perubahan. Jember: STAIN Jember Press bekerjasama dengan Pustaka Pelajar, 2015.

Chittik, William C. The Sufi Path of Knowledge (Tuban Sejati Dan Tuban-Tuban Palsu). Yogyakarta: Qalam, 2001.

Frager, Robert. Psikologi Sufi: Untuk Transformasi Hati, Jiwa, Dan Ruh. Jakarta: Zaman, 2014.

Hadi W.M, Abdul. "Amang Rachman: Antara Surealisme Dan Sufisme.” Berita Buana, Nopember 1984. 
- "Amang Rahman: Pelukis Surealisme Sufistik Dan Kaligrafi." Media Indonesia, April 25, 1990.

—. Islam, Cakarawala Estetik Dan Budaya. Jakarta: Pustaka Firdaus, 2000.

—. "Pelukis Amang Rahman Dalam 'Diam' Menuju Puncak Estetika." Jayakarta, September 8, 1988.

Ibnu 'Arabi, Muhyiddin. Misteri Kun: Syajaratul-Kaun. Surabaya: Risalah Gusti, 2005.

Jacobsen, Frode F. Hadrami Arabs in Present-Day Indonesia, An Indonesia-Oriented Group with an Arab Signature. USA-Canada: Routledge, 2009.

Mujiburrahman. Agama, Media Dan Imajinasi: Pandangan Sufisme Dan Ilmu Sosial Kontemporer (Pidato Pengukuhan Guru Besar Sosiologi Agama). Banjarmasin: IAIN Antasari Press, 2015.

Nasr, Seyyed Hossein. Spiritualitas Dan Seni Islam. Bandung: Mizan, 1993.

- Tasauf Dulu Dan Sekarang. Jakarta: Pustaka Firdaus, 2002.

Nurcahyo, Henri, and Mamannoor. Ambang Cakrawala. Jakarta: Yayasan Kembang Jati, 2001.

Pirous, A.D. Melukis Itu Menulis. Bandung: Yayasan Serambi Pirous dan Penerbit ITB, 2003.

Schimmel, Annemarie. Dan Mubammad Utusan Allah, Cahaya Purnama Kekasib Tuhan. Bandung: Mizan, 2012.

Schoun, Frithjof. Mencari Titik Temu Agama-Agama. Jakarta: Pustaka Firdaus, 1987.

Sudarmanto. Tinjauan Seni Lukis Amang Rabman Jubair Periode Tabun 1990- 1993. Skripsi tidak diterbitkan. Fakultas Pendidikan Bahasa dan Seni, IKIP Surabaya, Surabaya, 1994.

Van den Berg, L.W.C. Orang Arab Di Nusantara. Depok: Komunitas Bambu, 2010.

Wisetrotomo, Suwarno. Imaji Surga Biru Amang Rabman" Katalog Pameran Imaji Surga Biru Amang Rahman. Yayasan Kembang Jati, 2001. 


\section{Lampiran:}

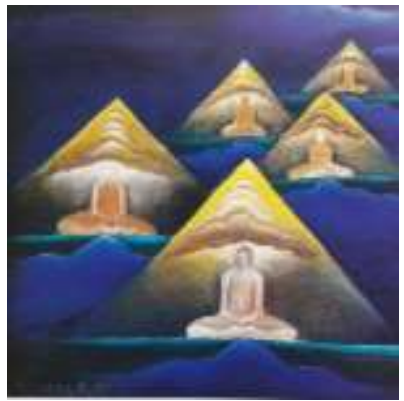

Lukisan Piramid

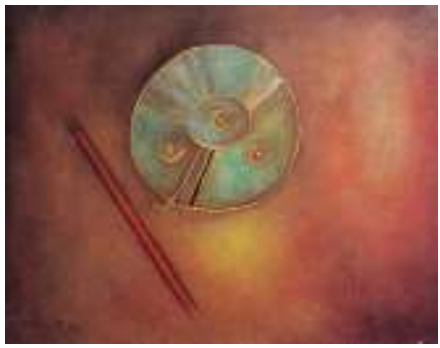

Lukisan Simbol Purba II

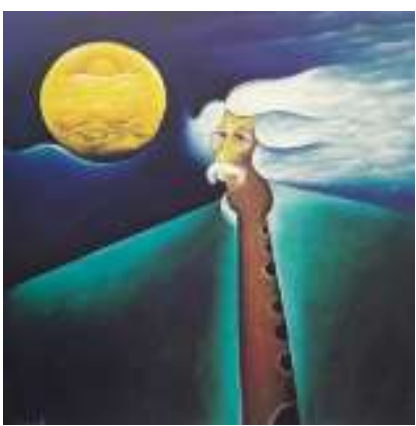

Lukisan Potret Diri

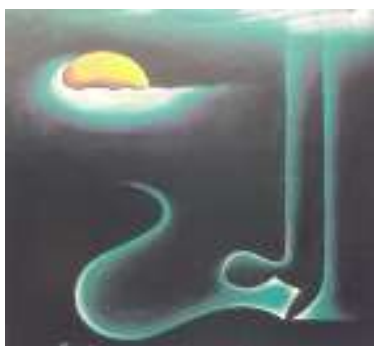

Lukisan Alif Laam Mim

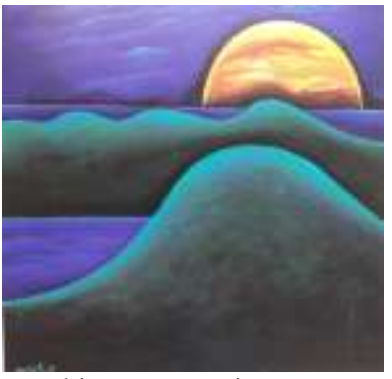

Lukisan Impresi Lasem I

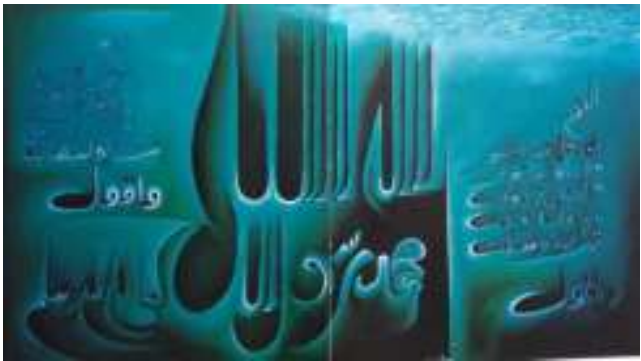

Lukisan Sebahagian Do’a Akasyah

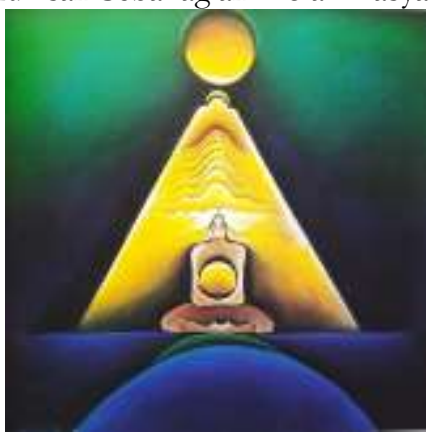

Lukisan Lalu Kudekap Dia

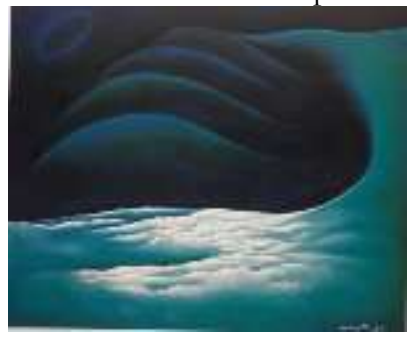

Lukisan Pegunungan Cangar 
26 AL-BANJARI

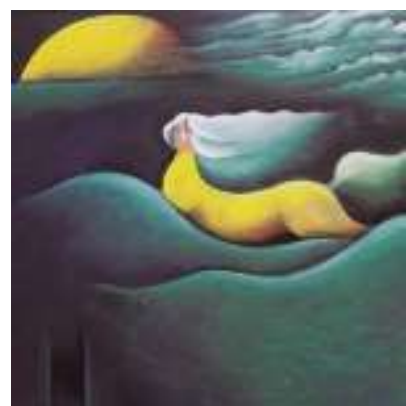

Lukisan Perjalanan

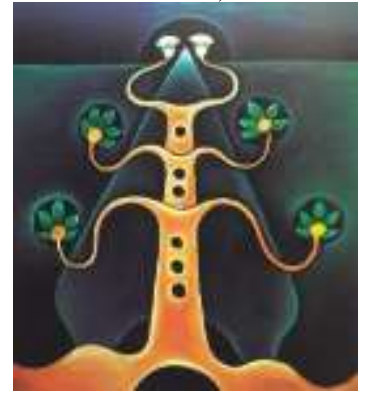

Lukisan Pohon Kehidupan dan Dua Bunga
Vol. 16, No.1, Januari-Juni 2017

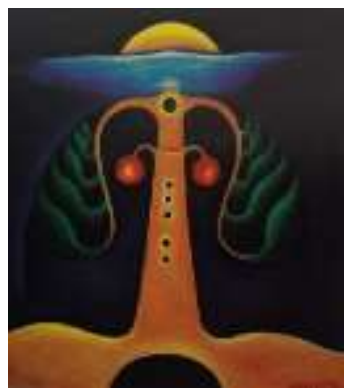

Lukisan Pohon Kehidupan dan Dua Buah 